\title{
The Influence of the Reference Area of Aileron on the N2XX Aircraft Using Computational Fluid Dynamics
}

\author{
Siti Nur Rahmah ${ }^{*}$, Gaguk Jatisukamto², Hary Sutjahjono ${ }^{2}$ \\ ${ }^{1}$ Bachelor Program of Mechanical Engineering Department, Jember University, Jl. Kalimantan 37, 68121, \\ Jember, Indonesia \\ ${ }^{2}$ Mechanical Engineering Department, Jember University, Jl. Kalimantan 37, 68121, \\ Jember, Indonesia \\ *Corresponding author: snrahmah.id@gmail.com
}

\begin{abstract}
Aileron is a control surface that functions as a regulator of roll motion. The movements of the ailerons are opposite to the left and right sides. Previous studies have shown that graphs of hinge moment coefficient $\left(\mathrm{C}_{\mathrm{hm}}\right)$ values increases with increasing angle of attack. This study is to determine the aerodynamic characteristics of aileron by combining the surface area of the vane into the aileron by varying the aileron's deflection. The calculation is performed using a numerical method in two dimensions (2D) commercial CFD simulation software. The results of the study concluded that the hinge moment coefficient for modified airfoil at $\delta \mathrm{A}=-20^{\circ}, 0^{\circ}$, and $20^{\circ}$ was $-0.071,0.078$, and 0.177 , respectively. These values are smaller when compared to $\mathrm{C}_{\mathrm{hm}}$ value in basic aileron that was $-0.094,0.095$, and 0.201 , respectively.
\end{abstract}

Copyright (C) 2020. Journal of Mechanical Engineering Science and Technology

All rights reserved

Keywords: Aileron, computational fluid dynamics, hinge moment coefficient.

\section{Introduction}

Indonesia is an archipelago with 16.056 islands [1]. The geographical location of Indonesia, which is separated by seas and mountains, has led to uneven development in Indonesia. Modes of air transportation are a good choice for connecting between islands and remote areas. Airplanes have good time effectiveness compared to land and sea transportation modes [2]. These considerations encourage PT. Dirgantara Indonesia and LAPAN worked together to make a pioneering aircraft named the N2XX aircraft.

$\mathrm{N} 2 \mathrm{XX}$ aircraft has a control surface that regulates the basic movements of the aircraft, including ailerons (roll), elevators (pitch), and rudder (yaw). The pilot regulates the movement of the control surface through the aircraft cockpit [3]. An aircraft control system is a system that functions to control an aircraft using an aerodynamic control surface. Aileron is a control surface for the movement of roll on the longitudinal axis. Aileron mounted on the left and right wings of the aircraft with deflection movements that are opposite each other in direction. Increased aileron deflection will affect the coefficient of drag, lift, and hinge moment [4].

Zhang et al. [5] investigated the hinge moment characteristics generated by the ONERAM6 wing with aileron. The method used was a three-dimensional (3D) simulation. The research parameters are variations in the gap, angle of attack (AOA) and aileron deflection 
angle $\left(\delta_{\mathrm{A}}\right)$ angle. The results showed that a greater gap and $\delta_{\mathrm{A}}$ angle could produce hinge moment curves that bend upward at high AOA.

Makarov and Pavlenko [6] examined the effectiveness of ailerons on high lift wing airfoils. The method used is a simulation with a two-dimensional (2D) CFD method by varying the nose contour on the aileron. The results showed that the parabolic nose contour has a lower hinge moment value and higher efficiency than the nose circular arc. Herdiana et al. [7] studied the hinge moment aileron on national transport aircraft. The method used is a 2D CFD simulation using Fluent software with AOA and $\delta_{\mathrm{A}}$ angle variations. The results showed that the graph of $\mathrm{C}_{\mathrm{hm}}$ is linear, so with a certain increase in AOA the hinge moment value is absolute and will be enlarged depending on the orientation $\delta_{\mathrm{A}}$ angle. Wijiatmoko et al. [8] investigated aileron effectiveness on the PUNA Alap-alap Aircraft. The method used was experimental using a wind tunnel test with a variation of the $\delta_{\mathrm{A}}$ angle $=0^{\circ}$ to $-25^{\circ}$. The results of the study concluded that the $\delta_{\mathrm{A}}$ angle was still quite effective up to $-25^{\circ}$. The decrease in effectiveness occurs when the angle of attack approaches the stall angle for all $\delta_{\mathrm{A}}$ angles.

$\mathrm{N} 2 \mathrm{XX}$ aircraft development is being carried out related to the effectiveness of aircraft ailerons in order to get a good $\mathrm{C}_{\mathrm{hm}}$ value which is close to 0 . The smaller $\mathrm{C}_{\mathrm{hm}}$ value of aileron will make the use of wheel force lighter by pilots to run the aileron when they want to roll. The results of a literature review search show that research on the influence of AOA and $\delta \mathrm{A}$ has been carried out. Research on the influence of the aileron surface area is still being developed. The purpose of this study was to determine the effect of aileron area and aileron deflection using the two-dimensional Computational Fluid Dynamics (CFD) simulation method so that it can determine the aerodynamic characteristics of the aileron.

\section{Material and Methods}

The study was conducted at PT. Dirgantara Indonesia, especially in the Aerodynamics Division. This study uses a 2D simulation method using commercial CFD software. Environmental parameters for aileron based on wind tunnel test conditions at PT. Dirgantara Indonesia.

The airfoil used in this study was LS (01)-0417 MOD. Airfoil for validation is a whole airfoil that has not been split into vane, aileron, and trim tabs. Airfoil LS (01)-0417 MOD used for validation can be seen in Figure 1. Validation is done by comparing the lift coefficient $\left(\mathrm{C}_{1}\right)$ of the WTT result with the simulation result. Validation is using grid independency mesh to determine the meshing that will be used in this aileron study.

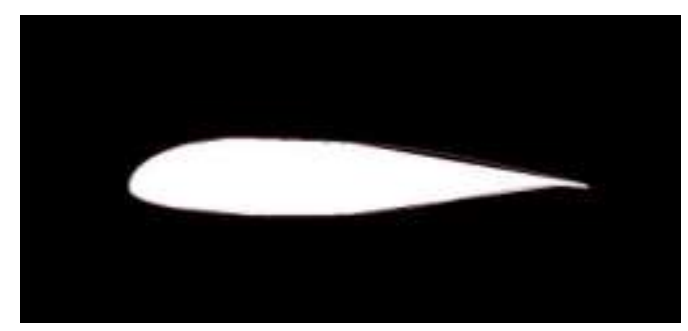

Fig. 1. The airfoil of LS (01)-0417 MOD [9]

The research airfoil used was the N2XX Aircraft wing which consisted of several parts. Airfoil research uses two variations of aileron, namely basic and modification. The airfoil of 
basic aileron consists of four parts, namely the main wing, vane, aileron, and trim tab. While the modified aileron only consists of wing, aileron, and trim tab. The design of basic and modified aileron can be seen in Figure 2 and Figure 3. This research conducted aileron deflection variation $\left(\delta_{\mathrm{A}}\right)$ of $-20^{\circ}, 0^{\circ}$, and $20^{\circ}$.

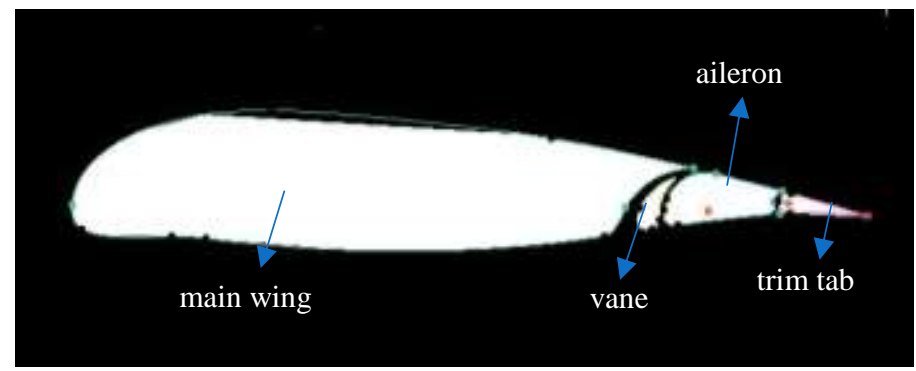

Fig. 2. Basic aileron [10]

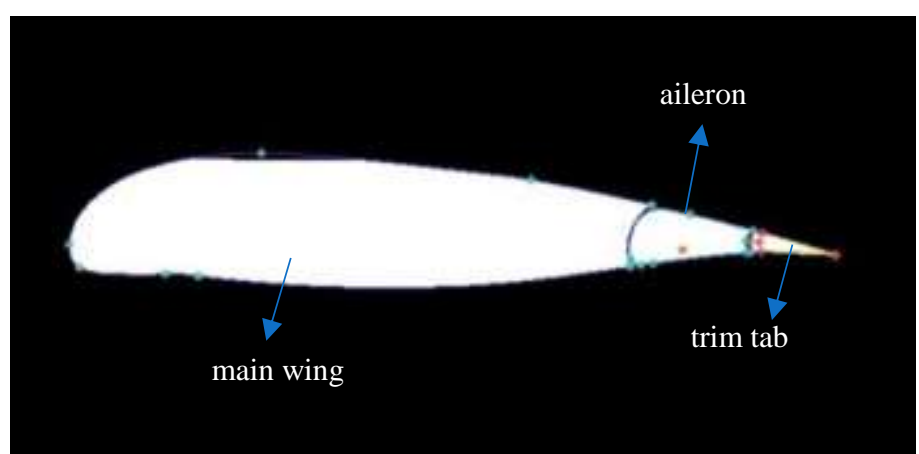

Fig. 3. Modified aileron [10]

This simulation uses boundary condition input adjusted to the wind tunnel test data from PT. Dirgantara Indonesia (Persero). The boundary condition can be seen in Figure 4.

Table 1. Fluid domain

\begin{tabular}{lr}
\hline Name & Distance \\
\hline $\mathrm{AD}=\mathrm{BE}=\mathrm{CF}$ & $20 \times$ chord \\
$\mathrm{AB}=\mathrm{BC}$ & $12.5 \times$ chord \\
\hline
\end{tabular}

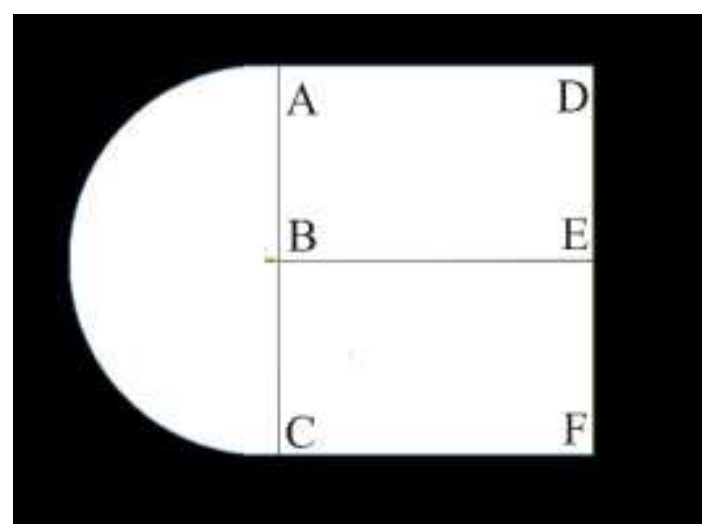

Fig. 4. Fluid domain 
The parameters set in this study is shown in Table 2 .

Table 2. Input parameters

\begin{tabular}{lr}
\hline Parameters & Value \\
\hline Type Solver & Density-Based \\
Input & Pressure Far-Field \\
Mach Number & 0.2 Mach \\
Operating Pressure & $101325 \mathrm{~Pa}$ \\
Turbulence model & Viscous k- $\omega$ SST \\
Temperature & $300 \mathrm{~K}$ \\
Chord length & $1.7102 \mathrm{~m}$ \\
\hline
\end{tabular}

\section{Results and Discussions}

The simulation results from this research are coefficient value and velocity contour analysis.

\section{A. Validation}

Validation of the LS (01)-0417 MOD airfoil uses variations in the value of $\mathrm{y}^{+}$as an independence mesh. This study uses the k- $\omega$ SST turbulence model. Validation results can be seen in Table 3 .

Table 3. Validation result

\begin{tabular}{lrrrrr}
\hline & Element & $\mathrm{Y}^{+}$ & $\mathrm{C}_{1}$ of simulation & $\mathrm{C}_{1}$ of WTT & Error \\
\hline Mesh 1 & 69,724 & 0.944 & 0.37757 & 0.41 & $7.91 \%$ \\
Mesh 2 & 91,574 & 0.75 & 0.37761 & 0.41 & $7.9 \%$ \\
Mesh 3 & 363,724 & 0.64 & 0.39458 & 0.41 & $3.76 \%$ \\
\hline
\end{tabular}

The result of this method at angle of attack $\alpha=0^{\circ}$, Lift coefficient $\left(\mathrm{C}_{1}\right)$ was calculated for wall $\mathrm{Y}^{+}$value and compared with experimental data of wind tunnel test from NASA [9]. McGhee and Beasley [9] contained experimental data of $\mathrm{C}_{1}$ for LS (01)-0417 MOD. The error of this simulation and experimental data is not allowed bigger than $10 \%$. The validation results show that Mesh 3 has the smallest $\mathrm{C}_{1}$ error of $3.76 \%$. The small error is caused by Mesh 3 has a better mesh density so that it produces a better mesh in the layers around the airfoil wall. Mesh 3 is chosen as meshing, which will be applied to the aileron simulation.

\section{B. Simulation Results Data}

Table 4 shows the drag coefficient $(\mathrm{Cd})$ of the basic aileron when $\delta \mathrm{A}=-20^{\circ}$ and $20^{\circ}$ are 0.072 and 0.089 , respectively. This value is smaller than the $\mathrm{Cd}$ of the modified aileron of 0.075 and 0.100 , respectively. The lift coefficient $\left(\mathrm{C}_{1}\right)$ of the modified aileron when $\delta_{\mathrm{A}}=$ $-20^{\circ}$ and $0^{\circ}$ are -0.114 and 0.452 , respectively. This value is higher than $\mathrm{C}_{1}$ of basic aileron of -0.125 and 0.446 , respectively.

Herdiana et al. [7] studied the aileron hinge moment coefficient of national transport aircraft basic. Figure 5 shows the curves of $\mathrm{C}_{\mathrm{hm}}$ for various aileron deflected angle, compared 
with Herdiana's report at an angle of attack $\alpha=0^{\circ}$. The value of $\mathrm{C}_{\mathrm{hm}}$ from the two aileron shapes is not very close to simulation data by Herdiana et al. Herdiana's report shows that $\mathrm{C}_{\mathrm{hm}}$ at $\delta_{\mathrm{A}}=-20^{\circ}$ is bigger than the two aileron shapes at the same deflection. The hinge moment coefficient $\left(\mathrm{C}_{\mathrm{hm}}\right)$ of the modified aileron when $\delta_{\mathrm{A}}=-20^{\circ}, 0^{\circ}$, and $20^{\circ}$ is -0.071 , 0.078 , and 0.177 , respectively. This value is smaller than the $\mathrm{C}_{\mathrm{hm}}$ of aileron basic, each of which is $-0.094,0.095$, and 0.201 , respectively. The cause of $\mathrm{C}_{\mathrm{hm}}$ produced by a modified aileron is lower than the basic aileron is the increase in the area of the modified aileron. The surface area in front of the hinge line will be able to produce a higher counter moment so that it will reduce the moment behind the hinge line.

Table 4. Data of simulation

\begin{tabular}{lrrrr}
\hline Geometry & $\delta_{\mathrm{A}}$ & $\mathrm{C}_{\mathrm{d}}$ & $\mathrm{C}_{\mathrm{l}}$ & $\mathrm{C}_{\mathrm{hm}}$ \\
\hline \multirow{3}{*}{ Basic } & $-20^{\circ}$ & 0.072 & -0.125 & -0.094 \\
& $0^{\circ}$ & 0.047 & 0.446 & 0.095 \\
& $20^{\circ}$ & 0.089 & 1.334 & 0.201 \\
\hline \multirow{3}{*}{ Modified } & $-20^{\circ}$ & 0.075 & -0.114 & -0.071 \\
& $0^{\circ}$ & 0.045 & 0.452 & 0.078 \\
& $20^{\circ}$ & 0.100 & 1.207 & 0.177 \\
\hline
\end{tabular}

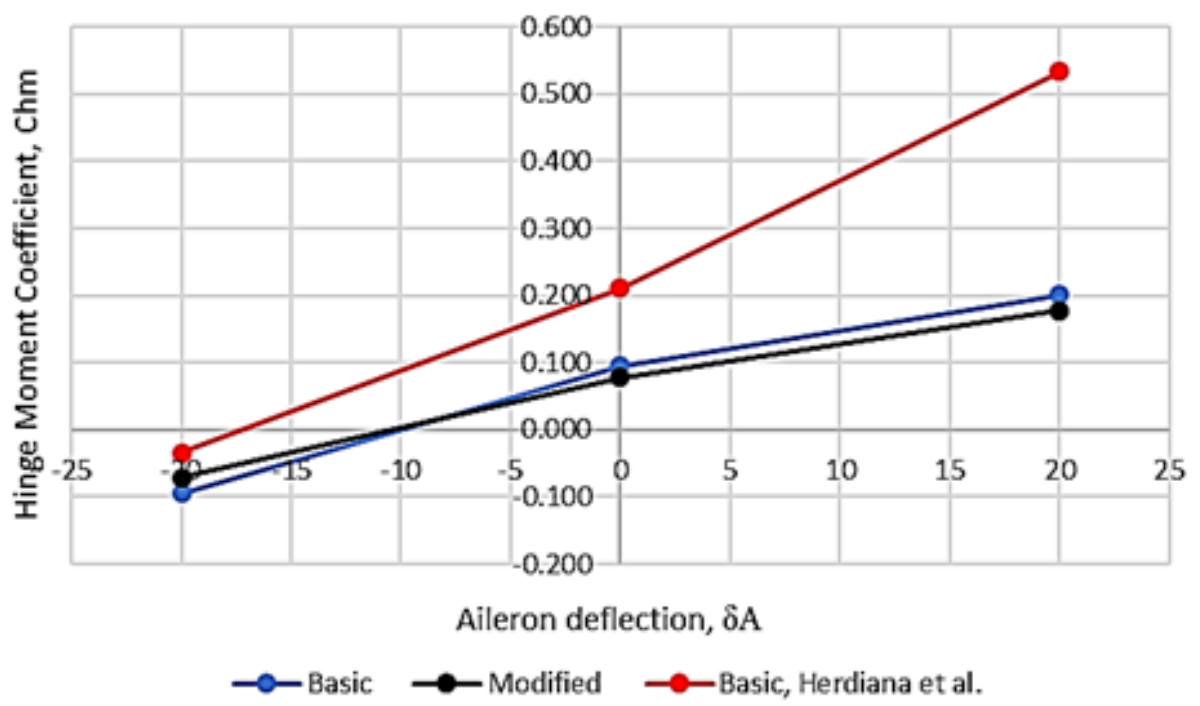

Fig. 5. Comparison between simulation data for aileron design from Herdiana et al. [7] and two different aileron shape result of the hinge moment coefficient curve for N2XX aircraft aileron.

\section{Analysis of Velocity Contour}

Aileron analysis is performed using velocity contours. In the velocity contour display (Figure 6), we can see the range of velocity values at a point or area of the colormap on the left. The red color indicates a high-velocity value, while the blue value indicates a lowvelocity value. 

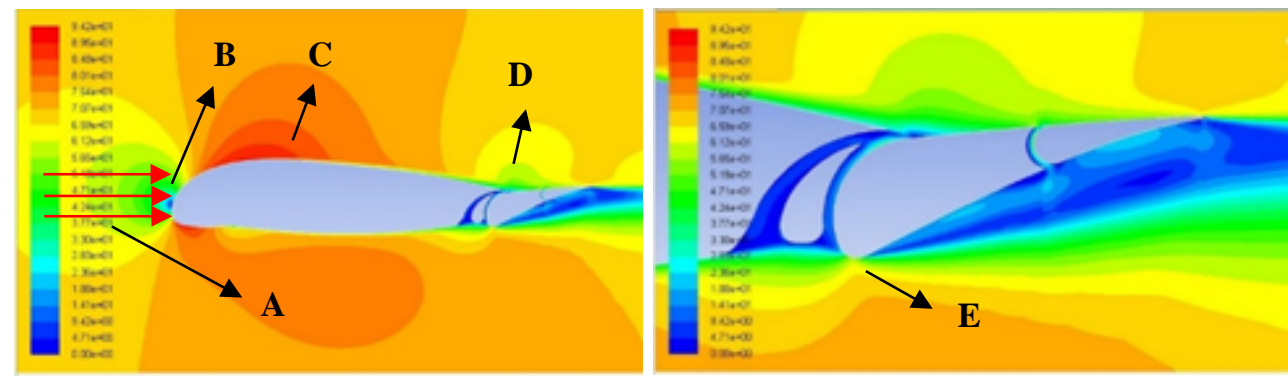

(a)

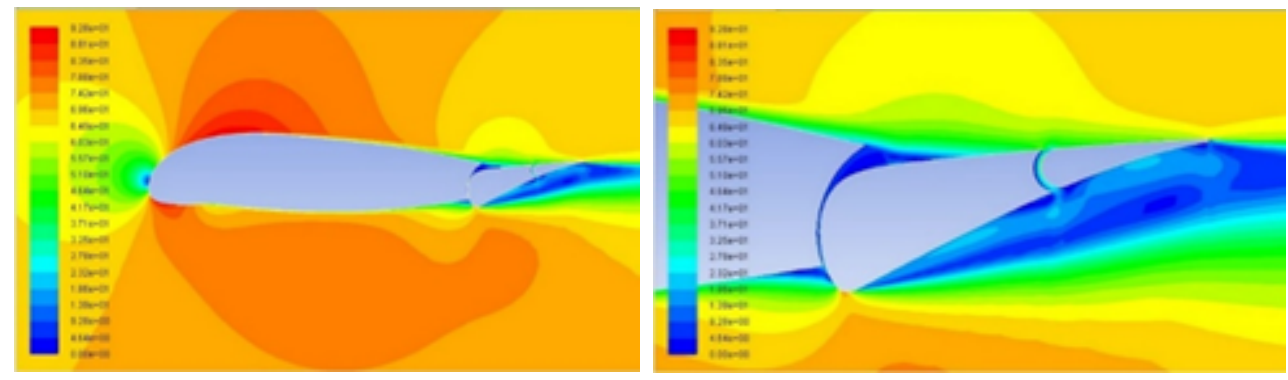

(b)

Fig. 6. Velocity contour at deflection of $-20^{\circ}$. (a) Basic aileron; (b) Modified aileron. Caption: $\mathrm{A}=$ direction of flow; $\mathrm{B}=$ stagnation point; $\mathrm{C}=$ laminar separation bubble $(\mathrm{LSB}) ; \mathrm{D}=$ bubble; $\mathrm{E}=$ separation

Figure 6 shows the velocity contour at $\delta_{\mathrm{A}}=-20^{\circ}$. Stagnation occurs at the leading edge, causing local velocity of the fluid to decrease to zero, as shown in Figure 6 [11]. Flow flowing on the upper surface will experience a laminar separation bubble (LSB) which can be seen at point C. LSB is formed in the upper surface area in the second airfoil. LSB is formed in the boundary layer, which causes the transition from laminar to turbulent [12]. LSB on the wing modification looks bigger than on the basic wing. The resulting coefficient of drag $\left(\mathrm{C}_{\mathrm{d}}\right)$ will be greater if the LBS that is formed is getting bigger.

Flow visualization also shows that shortly after reattachment of the two wings, separation occurs and creates bubble separation on the upper surface of the aileron which can be seen at point D. Bubble separation occur as a result of weak momentum flowing through the underside of the wing to meet the flow with large momentum so give rise to flow blockage [13]. Figure 6(b). shows the bubble separation that occurs over a modified sloping aileron because there is a change in the geometric contour on the trailing edge wing. The pressure that occurs on the upper surface of the modified aileron becomes smaller so that it will increase the coefficient of lift $\left(\mathrm{C}_{1}\right)$.

The separation was seen at the lower surface of the two ailerons at point $\mathrm{E}$. The modified aileron appeared to undergo turbulized separation first. The advanced separation of the modified aileron is due to the increased deflected surface at the leading edge of the aileron. This separation can cause the value of the drag coefficient on the modified aileron to be higher [6].

The area that deflects the modified aileron has a wider reference area than the basic aileron. The addition of the cross-sectional area to the aileron will have an impact on the value of the hinge moment coefficient. The counter moment which serves to reduce the moment to the area behind the hinge line becomes higher [14]. This counter moment will cause the hinge moment coefficient $\left(\mathrm{C}_{\mathrm{hm}}\right)$ value to be smaller. 

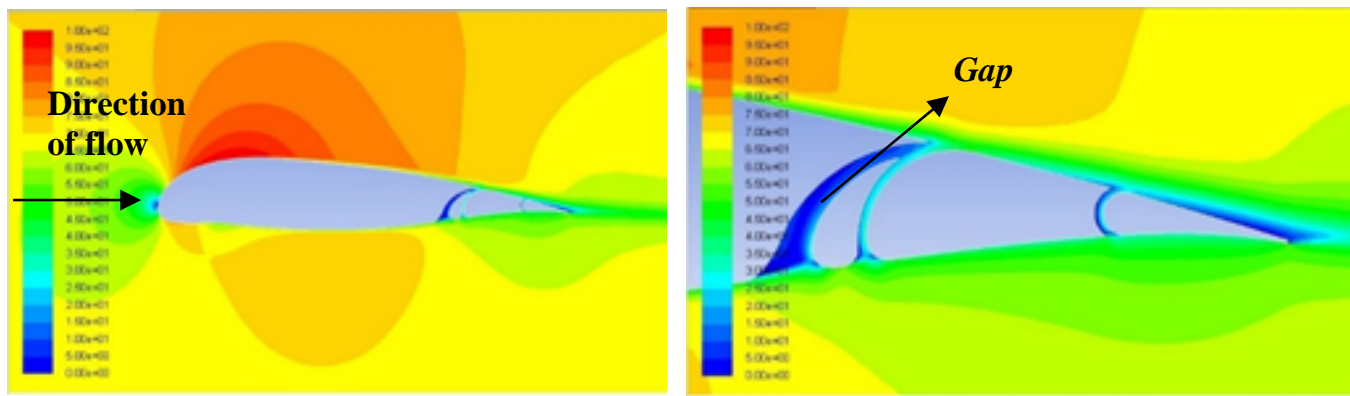

(a)

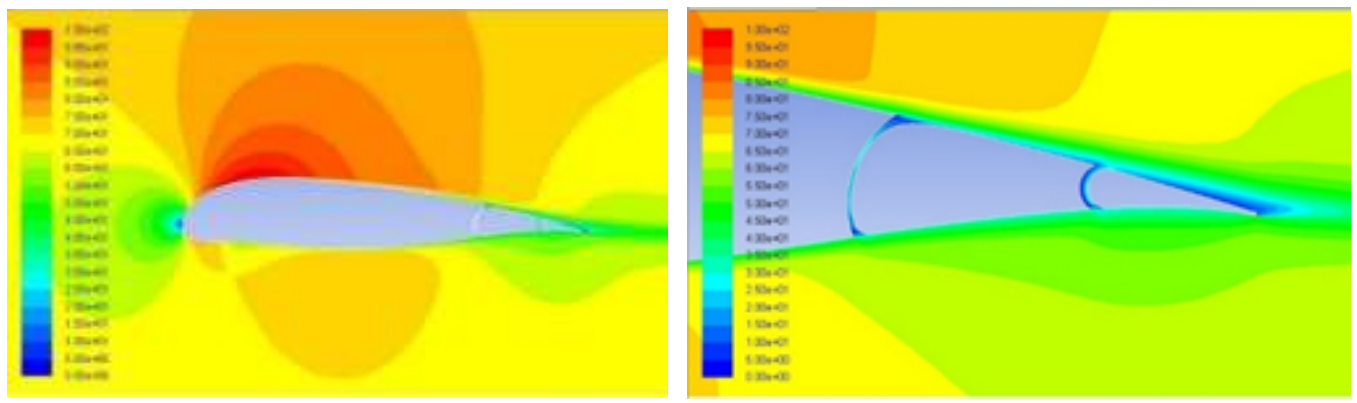

(b)

Fig. 7. Velocity contour at deflection of $0^{\circ}$; (a) Basic aileron; (b) Modified aileron

Figure 7. shows the velocity contour at $\delta_{\mathrm{A}}=0^{\circ}$. The velocity contour at $\delta_{\mathrm{A}}=0^{\circ}$ on the leading edge of the wing does not show a significant difference, as seen in Figure 7 . The difference is clearly seen in the gap between the wing and aileron. Basic airfoil has a wider gap due to the presence of vane. A wide gap will cause low-velocity flow to accumulate in the gap [14]. The gap on basic aileron has a larger area so that the resulting drag coefficient becomes larger, as shown in Figure 7(a).

The separation that occurs in the lower surface of the two wings looks no different. The decrease in velocity occurs after separation, which is marked by the presence of green contours on the lower surface wing to trim tabs on both ailerons. The green velocity contour indicates a lower flow velocity compared to the yellow contour below. Declining velocity indicates that the pressure that occurs in the area becomes greater. The area of the modified aileron that is reached by a large pressure is wider than the basic aileron depicted in Figure 7(b), so that the resulting lift coefficient becomes larger.

The area that deflects the modified aileron has a wider reference area than the basic aileron. The addition of the cross-sectional area to the aileron will have an impact on the value of the hinge moment coefficient. The counter moment which serves to reduce the moment to the area behind the hinge line becomes higher [14]. This counter moment will cause the hinge moment coefficient $\left(\mathrm{C}_{\mathrm{hm}}\right)$ value to be smaller.

Figure 8. shows the velocity contour at $\delta_{\mathrm{A}}=20^{\circ}$. LSB at the speed contour is formed in the upper side region on both airfoils. Figure 8(b). shows the LSB on the modified wing having a redder color contour than the basic wing. This indicates that more low-pressure flow accumulates in the wing modification area, so that drag will increase [12]. 

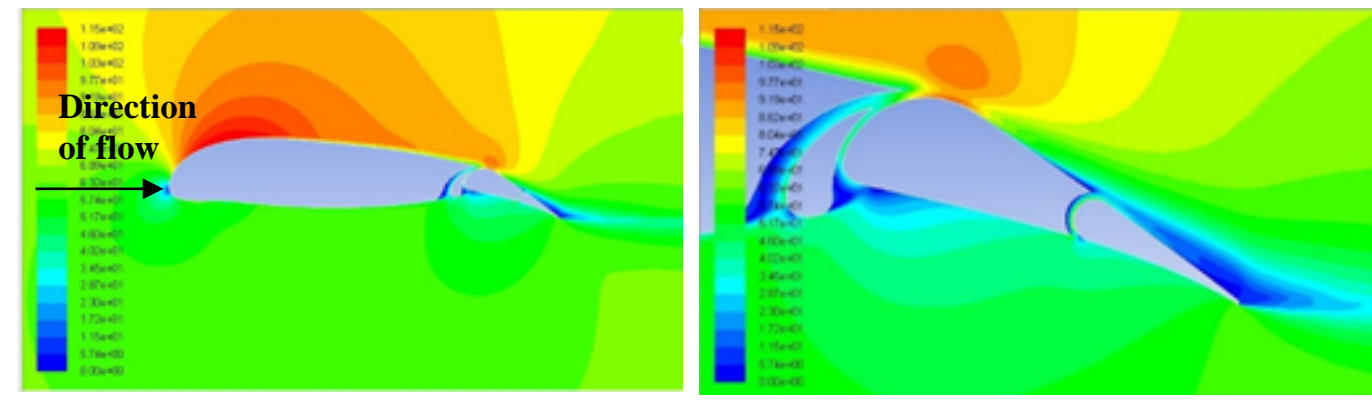

(a)
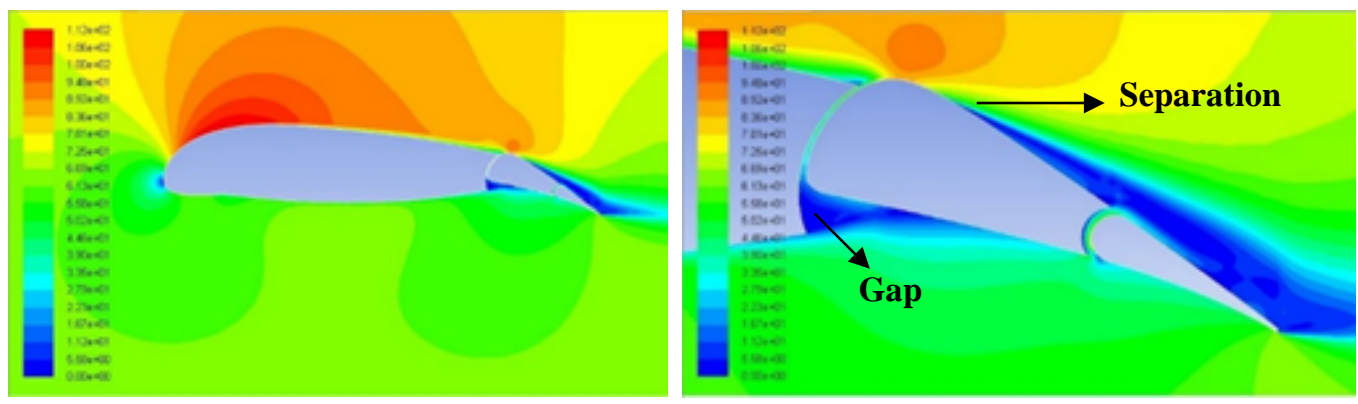

(b)

Fig. 8. Velocity contour at deflection of $20^{\circ}$. (a) Basic aileron; (b) Modified aileron

The aileron that deflects at $20^{\circ}$ makes the modified aileron nose protrude. Separation occurs after the bubble on the upper surface of the two ailerons. Separation of the modified aileron occurs first so that the free flow produces a greater weak [6]. This separation makes the $\mathrm{Cl}$ value in the modified aileron lower than the basic aileron, as shown in Figure 8(b).

\section{Conclusions}

This paper showed the behavior of the aileron of N2XX aircraft at various aileron deflected angle. The validation was conducted to comparing the simulation and experimental data. The validation meshing for $\mathrm{Y}^{+}$value is obtained that $\mathrm{Y}^{+}=0.64$. has the smallest lift coefficient error $\varepsilon=3.760 \%$. By this method, the computational results agreed well with corresponding experimental data.

The simulation is continued by using the validation meshing results of $\mathrm{Y}^{+}$value. Basic aileron on $\mathrm{N} 2 \mathrm{XX}$ aircraft has a greater hinge moment coefficient compared to modified aileron of author version. This is due to changes in surface area in the aileron area. Changes in the area in front of the hinge line will increase the value of the counter moment, so the resulting hinge moment coefficient will be smaller. However, it is necessary to make improvements to the modified nose aileron design so that it will be able to reduce the $C_{d}$ value and increase the value of $\mathrm{C}_{1}$.

\section{Acknowledgment}

The authors would like to thank PT. Dirgantara Indonesia, for providing research support facilities. 


\section{References}

[1] Badan Pusat Statistik, Statistik Indonesia, Badan Pusat Statistik, Jakarta. 2019.

[2] Kementrian Perhubungan, Kriteria Penyelenggaraan Angkutan Udara Perintis di Indonesia, Available from: hubud.dephub.go.id/?id/news/detail/2833, 2016.

[3] R. H. Barnard, and D. R. Philpott, Aircraft Flight 4th ed, Pearson Education Limited, Harlow, 2010.

[4] Federal Aviation Administration (FAA), Pilot's Handbook of Aeronautical Knowledge, U.S. Department of Transportation, 2016.

[5] G. Q. Zhang, S. C. M. Yu, and A. Chien, "Investigation of the Three-Dimensional Hinge Moment Characteristics Generated by the ONERA-M6 Wing with an Aileron", Advanced in Mechanical Engineering, vol. 5, pp. 1-11. 2013.

[6] K. A. Makarov and A. A. Pavlenko, "Numerical Investigation of an Aileron Hinge Moments and Effectiveness on a High Lift Wing Airfoil", in 29th Congress of the International Council of the Aeronautical Sciences, Curran Associates Inc. 1-10.

[7] D. Herdiana, S. T. Pinindriya, and R. Triwulandari, "Investigation of Aileron Hinge Moment of National Transport Aircraft Basic to Numeric Method", in International Seminar on Aerospace Science and Technology III, Institute of Physics Publishing (IOP), 45-51.

[8] G. Wijiatmoko, “Analisa Efektivitas Sudut Defleksi Aileron pada Pesawat Udara Nir Awak (PUNA) Alap-alap", in Seminar Nasional Inovasi dan Aplikasi Teknologi di Industri 2017, ITN Malang, 1-6.

[9] R. J. McGhee and W. D. Beasley, Wind-Tunnel Results for a Modified 17-PercentThick Low-Speed Airfoil Section, NASA TP-1919, 1981.

[10] PT. Dirgantara Indonesia, Report Data PT. Dirgantara Indonesia, PT. Dirgantara Indonesia, Bandung, 2016.

[11] D. C. Eleni, T. L. Athanasios, and M. P. Dionissios, "Evaluation of the Turbulence Models for the Simulation of the Flow over a National Advisory Committee for Aeronautics (NACA) 0012 Airfoil”, Journal of Mechanical Engineering Research, Portico, vol. 4(3), pp.100-111, 2012.

[12] R. Ma and P. Liu, "Numerical Simulation of Low-Reynolds-Number and High-Lift Airfoil S1223", in Proceedings of the World Congress on Engineering 2009, International Association of Engineers, 1-6.

[13] A. W. E. Sadewo and H. Sasongko, "Studi Eksperimen dan Numerik Pengaruh Slat Clearance serta Slat Angle untuk Mengeliminasi Stall pada Airfoil "Studi Kasus pada Airfoil NACA 2412”, Jurnal Teknik ITS, 4(1), pp.108-113. 2015.

[14] M. H. Amir, and Sarwono, "Analisa Nilai Hinge Moment Coefficient pada Pengaruh Bentuk Rudder Pesawat N-2XX dengan Variasi Defleksi Rudder $0^{\circ}, 10^{\circ}$, dan $25^{\circ}$ Berbasis Computational Fluid Dynamics", Jurnal Teknik ITS, 7(2), pp.140-145, 2018. 